\title{
Judicial versus Private Auctions: Better without Protection?*
}

Remates judiciales versus privados: ¿Mejor sin protección?

\author{
Ricardo D. PAREDES** \\ ANDRÉS CRISOSTO K.*** \\ PhiLIPPe Martí C.****
}

\begin{abstract}
Using a sample of 680 and 1,300 judicial and private auctions respectively, we analyze the effect on the wealth of those the law is intended to protect of different regulations applicable to each type of auctions. We find that consistent with a simple economic model, Courts assign judicial auctions in a discretional manner, and that the assigned auctioneers charge fees which are substantially higher than those allowed by law. While this behavior put the intended protection to debtor and creditor at risk, economic theory does not rule out a welfare enhancing effect. We test the hypothesis that the judicial auctions' design reduces the welfare of those intended to protect and, consistent with the predictions of our model, we find it is more likely for Courts to appoint the less effective auctioneers and that the net price received by creditors and debtors in judicial auctions is about $18 \%$ to $33 \%$ below those that could be obtained in private auctions.
\end{abstract}

Key words: Auctions, regulation, efficiency.

JEL Classification: $K 23, L 12$.

\section{Resumen}

Usando una muestra de 680 y 1.300 remates judiciales y privados, respectivamente, analizamos el efecto que los distintos tipos de regulación que se les aplican a cada tipo de remate tienen en la riqueza de aquellos que la ley procura proteger. Hallamos que, consistente con un modelo económico simple, las Cortes asignan los remates en forma discrecional y que los martilleros favorecidos

* We thank María Teresa Ruiz-Tagle, Ignacio Casas, Marcos Lima, Enzo Sauma, Oskar Nupia, the participants of the LACEA-Political Economy Network Annual Meeting- especially the comments and help of Valentina Paredes and those of an anonymous referee of Estudios de Economía, and the funding granted by Fondecyt, Project $N^{\circ} 1060691$. Usual disclaimers apply.

** School of Engineering, Pontificia Universidad Católica de Chile rparedes@ing.puc.cl, Vicuña Mackenna 4860, Santiago, Chile.

*** School of Engineering, Pontificia Universidad Católica de Chile.

****School of Engineering, Pontificia Universidad Católica de Chile. 
aplican tarifas sustancialmente mayores a las establecidas en la ley. Aunque tal comportamiento cuestiona la capacidad de las regulaciones en cuanto a no asignar discrecionalmente los martilleros y limitar los precios cobrados a los usuarios, teóricamente al menos, ello pudiera favorecer esta medida de eficiencia. Testeamos la hipótesis que el diseño regulatorio sobre los remates judiciales reduce el excedente de quienes supuestamente debiera favorecer y hallamos que las Cortes favorecen a los martilleros menos efectivos y que el precio neto recibido por los usuarios de remates judiciales es entre $18 \%$ y $33 \%$ inferior al que se obtiene en remates privados no sujetos a regulación.

Palabras clave: Remates, regulación, eficiencia.

Clasificción JEL: K23, L12.

\section{INTRODUCTION}

The effects institutions have on economic performance and development have been highlighted in different contexts (Levy and Spiller, 1997; Acemoglu and Robinson, 2012). Within a context of high variance, Chile is recognized for its advanced institutions, low corruption, and clear norms for doing business (Stone, Levy and Paredes, 1996; Kaufmann, 2005 International Transparency 2006). A main strength of the Chilean economy, in comparison to other heavily regulated Latin American economies, arises from the early adoption of marketoriented regulations, particularly in regard to the creation of clear and simple regulations (Spiller and Viana, 1993; Ramamurti, 1996, Harberger, 1985). A distinctive feature of this deregulation process was to end sectorial regulations with the exception of natural monopolies, leaving conduct regulations to Antitrust Institutions. This lifted restrictions on a number of activities, only to be executed by professional associations and union associates in areas such as ports, health, and transport.

While the general advantages of lifting formal restrictions to entry are widely recognized, its effects are not clear when the bottleneck for competition lies within other regulatory frameworks. In the case of auctions, and particularly with judicial auctions, barriers to be an auctioneer intend to limit abuses and favor transparent processes, due to the exacerbation of incentives when auctions are mandatory. When a debtor receives a loan, he or she commits to its payment by backing his or her promise through collateral. In the event that the collateral does not fully cover the debt, a Court may force the entity to pay with his or her assets. Consequently, the main issue fostered is to set a price for the asset-debtors and creditors will have contradictory incentives concerning that price. A way to provide an objective valuation of that asset is to obtain its market value through auctions. The purpose of judicial auctions is to avoid subjective valuation when one party is forced to sell.

However, forcing someone to sell in order to pay a given debt creates additional agency problems. If for example, selling all of the debtor's assets still does not pay his or her debt, receiving a higher price for those assets will only benefit the creditor. As a result of this, the debtor will not have any incentive to monitor auctioneers and to simulate a transaction with a "front man," this could 
lead to the reduction of prices and asset retention. The notion that judicial auctions are influenced by the misalignment of incentives is supported by anecdotal evidence. Thus, it is widely believed throughout Latin America-and particularly in Chile-that assets bought in judicial auctions are sold at low prices, making both creditors and debtors suffer as a result of collusion between auctioneers and those who bribe them (see also, Valdés, 2006, and El Mercurio, 2006). In the case of Honduras, the World Bank (2003) recommended ending the habit of judges having the discretion of selecting auctioneers, as a means to reduce corruption. In the case of Peru, the same bank recommended creating instances for private resolutions to avoid judicial auctions.

In sum, judicial auction regulations are intended to protect participating parties, guaranteeing that the auction will follow a clearly specified procedure to protect those that are notably vulnerable to corruption.

The deregulation process Chile experienced in the 1980 s ended entry restrictions in order to induce competition. However, to mitigate potential corruption and promote a more just and efficient process, two regulations solely applicable to judicial auctions, not to private auctions, remain: the order in which Courts must assign auctioneers and a fee ceiling. While some new auctioneer entry was produced, incentives suggest that these regulations could reduce welfare when the ceiling applied to auction fees do not lead to the appropriate efforts to get a higher price, or when the selected auctioneers are not the most efficient ones in obtaining a higher price. Consequently, the effect of these regulations on social welfare or in the wealth of those the law is intended to protect (creditor and debtor) is not a theoretical issue, but an empirical one.

The purpose of this paper is to analyze the incentives associated with such a regulatory design, applicable to the judicial sector in Chile, a country where reforms in that sector are heavily discussed (e.g., over Notaries and Real Estate Registrars). To do so, we take advantage of the coexistence of two different sets of regulations applicable to auctions in Chile, and use a unique database catered to this purpose. Analyzing different regulatory schemes within the same country is especially pertinent to the analysis and interpretation of the consequences of these regulations.

The paper is structured in three sections besides this introduction. The second section describes judicial auctions and the regulatory framework. The third section develops a simple testable model. The fourth section describes the data and the results, and the fifth section is the conclusion.

\section{Judicial Auctions}

France was the first country that regulated the practice of auctions. In 1576 an edict attributed to Henry II established the appointment of "assessors-sellers" to seize assets, appraise them and sell them through public auctions when the parties requested it or the law required it. In 1801, 80 positions of Public Auctioneers were instituted in France and the law forbade those who had not been awarded such a designation to carry out auctions. As time went by, some differences arose in the legislation of the different countries, particularly in the degree of freedom to organize and carry out auctions, but restrictions to entry remained in most countries (see, Shubik, 1983; Doyle and Baska, 2002). 
In Latin America and in Chile in particular, auctions began with the Spanish Colonization. Most auctions were and still are voluntary, and the need to protect parties in a growing industry particularly after the 1930s emerged. The first Chilean law enacted in 1953 (Decree Law No. 263) created the judicial system of Public Auctioneers. That same Decree instituted the system of public elections to fill the positions of Public Auctioneers by district; auctioneers were finally designated by the President of the Republic (Llach, 1988).

In practice, the procedure to designate auctioneers was an important barrier that created monopolies, since the incumbent rejected new nominations just as in a variety of activities in Latin America. ${ }^{1}$ However, in the 1980 s with a second wave of structural reforms and following the French trend, the restrictions to entry to become an Auctioneer came to an end. ${ }^{2}$ As in other sectors and activities, Chile allowed entry even to a greater extent than the State of Tennessee, the core of the Auctioning Activity in the United States (Rules of the Tennessee Auctioneer Commission, 2004).

Klemperer (1999) classifies two basic designs for the most common auctions: the ascending auction and the first-price sealed-bid auction, but other classifications also exist. In the ascending bid auction, also known as the English Auction, the price is raised successively until one bidder remains. In this type of auction, the auctioneer announces the prices, and the bidders are the ones that make the offers.

The literature has focused on the conditions that make one type of auction better than another. Vickrey (1961) established that the strategies of the participants under different types of auctions are the same. The capacity of different auctions to achieve some goals (social efficiency, money collection) has been in the center of the theoretical and empirical debate, particularly due to the relatively recent wave of privatization of the telecommunications spectrum (Kempeler, 2002). Such debate however, has not been present in the case of Judicial Auctions, where no innovation has been suggested to replace the English scheme. As compared to other regulatory changes, this is methodologically convenient since, as stated, the efficiency characteristics of the ascending offer auctions method, which is the only design used in judicial and private auctions in Chile and in Latin America, can be taken as given in a context where other regulatory changes are occurring.

In Chile, judicial auctions may be requested by a civil court, a municipal court or a criminal court that accepted a creditor's complaint. Then, the judge appoints one of the auctioneers listed in the Registry of Judicial Auctioneers. The auctioneer, at the moment he receives the goods, must issue a report containing all specifications established in the law. This seizure order must be duly signed by the Auctioneer and a Public Notary.

1 In the middle 1970s, most legal monopolies existing in Chile ended. Nowadays, some exceptions that have a similar origin to auctioneers are notaries and the Property Registrar. For an analysis of the nature of these monopolies, see Valdés (2006) and Abarca (2006).

2 The costs of the monopolies in auctions had already been detected in France. This had a key role in art auctions until the year 1950, when the country lost to British auctioneers Sotheby's, Christie's and Phillips, who, without any restrictions, gained more and more importance in the field. In 2005, the new auctioneers conducted more than $90 \%$ of international art sales (see www.diplomatie.gouv.fr). 
The auctioneers are accountable to the Court for the auction during a period of five business days after the auction has taken place. The auctioneer can deduct legal taxes, the cost of advertisements and the auctioneer's own fee from the auction price. Consequently, in the case of judicial auctions, the creditor receives the difference between the price paid by the bidder and the expenses associated with the auction.

In a context of heavy regulation for judicial auctions in Chile, the enactment of Law 18,118 in September 1982 produced an important deregulation. The main change was to end formal barriers of entry to be an auctioneer. Thus, the law ended the requirement to be named for the President and since then, anyone who satisfied minimum requirements could be. The law also liberalized fees in the case of non-judicial or voluntary auctions, and set limits in the case of judicial auctions. Thus, while there were no fees ceiling for voluntary auctions, something coherent with the freedom of entry in the case of voluntary auctions, a decreasing scale ceiling from $8 \%$ to $0.5 \%$ of the value of the good was maintained for judicial auctions, depending on the price of the goods, plus a fixed fee that also depended on the price set in the auction process.

The law requires Courts designate the auctioneers following the correlative order used in the official registrar, to avoid arbitrary designation. This regulation was to discourage judges from favoring one auctioneer over the rest in response to pressures, lobby or bribes. In turn, ending the requirements to become an auctioneer was aimed at inducing competition and efficiency. Finally, the maximum fees only imposed on judicial auctions were meant to limit the abuse on those debtors forced to sell their assets through judicial auctions.

The situation of judicial auctions contrasts with voluntary auctions. In the latter, sellers may compare different methods to sell their goods. They can sell in through different methods, including through a newspaper. When deciding the mechanism to sell they must consider the difficulty to sell through non auction methods and the expected price with the auctioneer's fees and his reputation to get good prices.

There is neither regulations on the price private auctioneer can charge nor on the auctioneer. This is natural, since the alternatives the seller has to sell his goods control the prices charged and the effort achieved.

\section{A Simple Model}

This section develops a simple model to compare the incentives for agents under different assumptions we associate with judicial and voluntary auctions and degrees of compliance with the law. In all cases we assume that each auctioneer maximizes its wealth $(W)$ that only depends on the net fee he charges and the number of auctions carries $(c-e)^{*} N$, where $\mathrm{c}$ is the fee charged which is a constant fraction $(\alpha)$ of the auction price $(P a)$; e is a measure of effort or expenses, and $N$ is the number of auctions carried. $P a$ depends exclusively on the effort made by the auctioneer (e), and we assume that the productivity of his effort is always positive but decreasing $P^{\prime} e>0$ and $P^{\prime \prime} e<0$.

Our purpose is to determine the optimal effort $e^{*}$ and the net price received by sellers $(P a-c)$ (the amount that will serve the debt), what we can consider is the most direct indicator of efficiency. Since $(P a-c)=P a(1-\alpha)$, this net price 
only depends on $e$. Consequently, from a public policy view, we are interested in finding out whether different regulatory schemes will induce different values for $e$. In particular, we analyze three cases; all assuming there is no collusion among auctioneers: i) private auctions, where clients choose the auctioneer, ii) judicial auctions with full compliance of the law regarding the order auctioneers are defined, and iii) judicial auctions with no compliance of the law regarding the incentives to define the auctioneer.

\section{i) Private Auctions}

For private or voluntary auctions, sellers have the chance to sell their goods directly or choose from different auctioneers. We assume that the number of auctions each auctioneer receives $(N)$ depends on his reputation, that increases with $(P a-c)$; that is, $N=f(P a-c)$, with $N^{\prime}>0$, and $N^{\prime \prime}<0$. Thus, the auctioneer maximizes:

$$
\Pi=\left(\alpha P_{a}(e)-e\right) \cdot N\left(P_{a}(e)\right)
$$

with FOC:

$$
\frac{\partial \Pi}{\partial e}=\left(\alpha P_{a}^{\prime}-1\right) \cdot N+\left(\alpha P_{a}-e\right) \cdot N^{\prime}=0
$$

Since $N,(\alpha P a-e)$ the margin, $N^{\prime}$ and $P a^{\prime}$ are positive, the FOC requires $\alpha$ $P a^{\prime}<1$.

The Second order condition is:

(3) $\frac{\partial^{2} \Pi}{\partial e^{2}}=\alpha P_{a}^{\prime \prime} \cdot N+\left(\alpha P_{a}^{\prime}-1\right) \cdot N^{\prime}+\left(\alpha P_{a}-e\right) \cdot N^{\prime \prime}+N^{\prime} \cdot\left(\alpha P_{a}^{\prime}-1\right)<0$

Since all terms are negative, this condition is satisfied.

\section{ii) Judicial Auctions, with full compliance of the law}

The main aspect in this case is that $N$ is independent of the auctioneer previous actions $\left(N^{\prime}=0\right)$. For instance, $N$ is random or it is taken sequentially from a list. Thus, the auctioneer maximizes:

$$
\Pi=\left(\alpha P_{a}(e)-e\right) \cdot N
$$

with FOC:

$$
\frac{\partial \Pi}{\partial e}=\left(\alpha P_{a}^{\prime}-1\right) \cdot N=0
$$


As can be seen in this case, the FOC requires that $\alpha P a^{\prime}=1$, and as $P a^{\prime \prime}<0$, the optimum e in judicial auction with full compliance of the law is lower than in the private auction case.

The second order condition.

$$
\frac{\partial^{2} \Pi}{\partial e^{2}}=N \alpha P_{a}^{\prime \prime}<0
$$

This condition, by assumption, is satisfied.

\section{iii) Judicial Auctions with partial compliance of the law}

Since sellers have no option to sell but through a judicial auctioneer and it is the Court official or the judge who determines the auctioneer, there is room to generate profits for both auctioneers and Court officials, at the expense of the agent whose assets are sold. One way to achieve these profits is that suggested in a number of complaints: the auctioneer sells the goods at a very low price to a pre-defined buyer. The possible profit, that we can assume is shared in fixed proportions between the Court official and the auctioneer, would be the difference between the market price and the auction price. Since the market price is given, the lower the auction price charged, the higher the probability that the purely profit-seeking Court official will designate a given auctioneer. ${ }^{3}$ In terms of our model, the number of designated auctions will fall with $\mathrm{Pa}\left(N^{\prime}<0, N^{\prime \prime}>0\right)$. Thus, again the auctioneer maximizes:

$$
\Pi=\left(\alpha P_{a}(e)-e\right) \cdot N
$$

FOC

$$
\frac{\partial \Pi}{\partial e}=\left(\alpha P_{a}^{\prime}-1\right) \cdot N+\left(\alpha P_{a}-e\right) \cdot N^{\prime}=0
$$

The FOC requires in this case that $\alpha P a^{\prime}>1$.

The second order condition is:

$$
\frac{\partial^{2} \Pi}{\partial e^{2}}=N^{\prime} \cdot\left(\alpha P_{a}^{\prime}-1\right)+N \cdot \alpha P_{a}^{\prime \prime}++\left(\alpha P_{a}-e\right) \cdot N^{\prime \prime}+N^{\prime} \cdot\left(\alpha P_{a}^{\prime}-1\right)<0
$$

Which it is always satisfied.

There are two implications of this model which are illustrated in Figure 1. First, the mechanism to allocate judicial auctions reduces welfare of those the law intended to protect, that is, debtors and creditors, but excludes transfers to

3 Note that in the case of private auctions, ex-post expropriations are also possible, though less convenient since $\mathrm{N}$ depends on the reputation created. 
auctioneers and their intermediaries, compared to voluntary auctions. The main difference is that judicial auctions induce less effort since part of the return on private auction efforts is given by the positive effect that e has on $N$. In turn, compliance of the law in the case of judicial auctions implies that e has no effect on $N$. Second, corruption is induced by judicial auctions since the seller has no choice and it is not neutral in social terms. This is because corruption reduces the price but also the additional effort made by the auctioneer.

FIGURE 1

EXPENDITURE AND CONSUMER NET PRICE UNDER PRIVATE AND JUDICIAL AUCTIONS

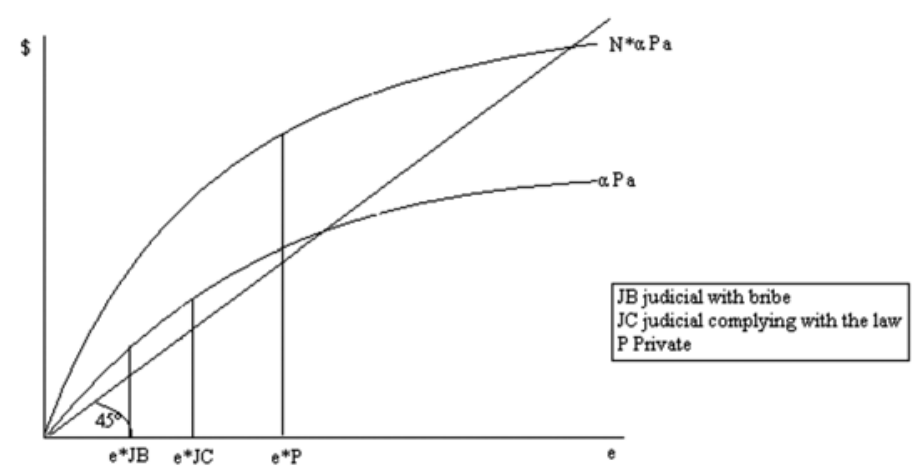

\section{Data ANd Results}

\subsection{Data}

To test the hypotheses derived from the model, we collected data from the judicial archives regarding judicial auctions for the period January 2004 and May 2006 in the seven main Civil Courts in Santiago, Chile $\left(21^{\text {st }}, 23^{\text {rd }}, 24^{\text {th }}, 25^{\text {th }}\right.$, $27^{\text {th }}, 29^{\text {th }}$ and $\left.30^{\text {th }}\right)$. We only considered car auctions since in these cases it is possible to get a better proxy for market prices and hence, to have a benchmark of the real prices, allowing us to derive a measure of auction efficiency. Civil Court auctions have the advantage that they keep and provide a detailed record of the condition of the goods sold. Furthermore, cars sold through judicial auctions ordered by Civil Courts are more likely to be in good condition, since the lawsuits which generate these auctions are mainly for default on the payment of the sale. In turn, this does not occur in the case of Criminal and in Municipal Courts, where a high proportion of cars are sold after suffering severe accidents.

The information contained in the records for each Court we examined included the identification of the plaintiff, the auctioneer assigned, the brand, model, and year of the car, the value of the complaint (\$), the selling price, the auctioneer's fees and advertising costs. Something particularly relevant for our 
purposes, there was also a detailed set of information about the quality of the car, certified in a car checklist form. We reviewed the files on the cars and we considered only cars reported in good condition so that it is possible to have better proxy for its market price.

Three samples were created. The first includes 440 cars in good condition that were actually sold through judicial auctions. The second sample includes 680 car assignments, that is, cars that were to be auctioned in the future, but that were not yet sold. For this sample, we did not make any analysis of the price, but we analyzed and described the assignment process. Finally, we got information on all private auctions done by over 50 auctioneers from Tattersal, a company specifically focused on conducting auctions of different kinds of assets, including vehicles. This database has information on more than 1,500 auctioned cars in the same period of 2 years considered in the dataset for judicial auctions. After depuration of cars with precise and complete information, the final sample for these voluntary auctions was 1,039 cars.

As derived from our simple model, a main issue for judicial auction institutions is auction effectiveness over the wealth of those intended to protect, creditors and debtors. A natural proxy for this specific definition of auction efficiency is the price received by who requires the auction in the case of voluntary auctions, or the margin left to pay toward the final debt in the case of judicial auctions, which we define as follows:

\section{(10) $A E=\frac{\text { Auction Price }- \text { Auctioneer Fee }- \text { Advertising Cost }}{\text { Market Price }}=\frac{\text { Net Price }}{\text { Market Price }}$}

A major challenge was to have a good proxy for the market prices of the auctioned cars. To get the market price for each car, we analyzed the selling prices in different media, and in particular, in the "cars for sale" section of the " $E l$ Mercurio," the newspaper with the most advertisements on a national level. For each car and model, we also considered the average price advertised, excluding those with evident flaws. We checked these prices with the valuation done by the IRS. On average, the average price calculated through the different methods do not differ by more than $1.5 \%$, so we choose the fiscal valuation considered for taxes as the estimator of the market price.

A first natural concern with using the advertised price as a proxy for the market price is that the former is an asking price, not a final price. This concern has no importance if the bias is not related to the fact that the auction is judicial or voluntary. A different and more relevant concern is that the quality of the cars sold through judicial auctions is presumably lower than that of cars sold voluntarily.

The condition of the car will affect its price and one could expect that cars sold through judicial auctions are in worse condition than those sold through voluntary auctions or through the newspaper because owners don't take care of them when they know they will lose them and that the price will not cover the whole debt. This possibility is reduced through the selection in our sample of cars only in good condition. Furthermore, an adverse selection effect may work in the opposite direction. In fact, Akeroff's adverse selection effect must be higher in the case of voluntary sells. On the other hand, if the concern about 
the bias in price comparisons is true, that only has implications for the interpretation of the value of our efficiency indicator, and does not have an effect on the estimated effect of efficiency and concentration or in the potential difference in price we may find between judicial and voluntary auctions. In particular, if Court officials by-pass the regulation that forces Courts to rotate among auctioneers, the hypothesis that they act on behalf of final consumers will predict a bias to allocate more auctions to those that are relatively good performers. On the contrary, if Court officials allocate cars in an adverse way, that is, to those auctioneers that perform worse, that evidence will be more consistent with the hypothesis that they do so for their own benefit. Consequently one hypothesis, as the one mentioned, does not depend on whether there is a systematic bias in the measurement of market price of cars sold through judicial auctions.

Table 1 shows a ranking of auction efficiency indicators for the 10 more efficient and ten least efficient judicial auctioneers measured through the mean efficiency indicator we have previously defined. The first column shows the AE, defined in (1), and the subsequent columns show the ratio between auction price and market price, the total number of auctions conducted by each auctioneer, and the number of Courts with assignments.

TABLE 1

EFFICIENCY OF THE FIRTS AND LAST 10 RANKED AUCTIONEERS

\begin{tabular}{|cccccc|}
\hline Ranking & $\begin{array}{c}\text { Net Auction } \\
\text { Price/Market } \\
\text { Price }\end{array}$ & $\begin{array}{c}\text { Auction Price/ } \\
\text { Market Price }\end{array}$ & $\begin{array}{c}\text { (Commission+Advertising) } \\
\text { Market Price }\end{array}$ & $\begin{array}{c}\text { \# of } \\
\text { auctions }\end{array}$ & $\begin{array}{c}\text { \# of } \\
\text { Courts }\end{array}$ \\
\hline 1 & 0.798 & 0.908 & 0.11 & 8 & 4 \\
2 & 0.778 & 0.935 & 0.157 & 7 & 4 \\
3 & 0.768 & 0.86 & 0.092 & 6 & 4 \\
4 & 0.761 & 0.849 & 0.088 & 2 & 2 \\
5 & 0.759 & 0.805 & 0.046 & 8 & 4 \\
6 & 0.74 & 0.746 & 0.006 & 4 & 3 \\
7 & 0.721 & 0.799 & 0.078 & 5 & 4 \\
8 & 0.715 & 0.846 & 0.131 & 13 & 5 \\
9 & 0.713 & 0.717 & 0.004 & 4 & 3 \\
10 & 0.711 & 0.788 & 0.077 & 3 & 3 \\
\hline 49 & 0.59 & 0.674 & 0.084 & 15 & 6 \\
50 & 0.582 & 0.666 & 0.084 & 7 & 5 \\
51 & 58 & 0.665 & 0.085 & 12 & 5 \\
52 & 0.577 & 0.608 & 0.031 & 12 & 5 \\
53 & 0.561 & 0.711 & 0.15 & 6 & 4 \\
54 & 0.561 & 0.633 & 0.072 & 3 & 3 \\
55 & 0.555 & 0.687 & 0.132 & 6 & 5 \\
56 & 0.538 & 0.623 & 0.085 & 9 & 4 \\
57 & 0.517 & 0.584 & 0.067 & 3 & 2 \\
58 & 0.474 & 0.526 & 0.052 & 2 & 2 \\
\hline
\end{tabular}


A striking observation is that on average, the efficiency indicator (Net Auction Price / Market Price) is about 0.65, which shows that the price finally received for those the law wants to protect is about $65 \%$ of the market price. This percentage may be affected by an eventual over representation of "lemons" in judicial auctions, something we doubt for the reasons previously mentioned. However, the difference of nearly 20 percentage points in the average efficiency of the ten most and the ten least efficient auctioneers suggests that important efficiency gains may be achieved. Furthermore, only about a half percentage point of this difference can be explained by different advertising costs and commission fees, so the main explanation for the different efficiencies is the auction price. Furthermore, the number of auctions that some of the least efficient auctioneers handle are substantially greater than the number of auctions handled by the more efficient.

\subsection{Fulfillment of the Law: Assignments and Fees}

The first question is whether regulations on fees and auctioneer assignments are fulfilled. It is worthwhile to emphasize that the law stipulates the designation is to be made following a correlative order derived from auctioneer registrations. Consequently, if this regulation were satisfied, each auctioneer should be designated with equal frequency. Since there are 76 registered auctioneers in each Court, by strictly adhering to the law, each auctioneer should have a similar participation, and this should be about $2 \%$. Our results show that each Court concentrates the auctions in fewer auctioneers than what would legally correspond, with concentrations surpassing twice as much as allowed. On average, the auctioneers with the greatest number of auctions concentrate between $7 \%$ and $9 \%$ of the auctions. This seems to reflect a preference for some auctioneers, which regardless of the legality, could affect the efficiency. ${ }^{4}$

In addition, the average auctioneer's fees largely exceed the legal limit. Considering the average transaction value of the cars auctioned by the different courts (US\$ 9,000), the legal fees applicable for those transactions should yield a maximum charge of about $4 \%$; actual fees, however, were about $10 \%$. Consequently, the two main regulations, maximum fees and assigning auctioneers sequentially, are not fulfilled.

A natural hypothesis is that not complying with these regulations has pervasive effects. A positive view however, would suggest that Courts assign more auctions to the most efficient auctioneers. To test that hypothesis, we check the correlation between the percentage of the auctions Court $\mathrm{j}$ assigned to auctioneer $\mathrm{i}$, on the measure of efficiency for each auctioneer through a simple regression. Finding a positive correlation would suggest that while Courts do not comply with the law, there is a positive effect on social welfare. A negative correlation, on the contrary, would be consistent with the hypothesis derived from the third case in our model, that is, a result consistent with corruption and bribes.

4 Judicial auctioneers cannot decline designated auctions by a given Court. 
While the $R^{2}$ of the regression is low, never exceeding $7 \%$, the results for all Courts suggest that the overrepresented auctioneers are never the most efficient ones. That is, for some Courts $\left(21^{\text {st }}\right.$ and $\left.30^{\text {th }}\right)$ there is a negative and significant coefficient associated with the efficiency variable, showing that for these two Courts, the selection has favored the least efficient auctioneers. On the other hand, even though all Courts have an unequal distribution of auctioneers, none shows that the most efficient auctioneers are over represented. In total, the evidence for at least two Courts is more consistent with case 3 in our model, that is, a case where the assignments are explained by bribes or are the consequence of collusive agreements between auctioneers and Court officials.

\subsection{Comparison between judicial auctions and private voluntary auctions}

The different efficiency among auctioneers reported in Table 1, the higher than regulated prices judicial auctioneers charge, and the lack of a positive correlation between efficiency and number of auctions in Courts, suggests that the net prices that finally will be used to pay the debt are lower than the market price.

In this section we compare the efficiency of auctions using the information provided by Tattersall S.A. Figure 2 shows histograms for both types of auctions, suggesting a clear difference in favor of the private auction. On average, the price through voluntary auctions is $97.79 \%$ of the market price, while the most efficient Court obtains, on average, $70.1 \%$ of the market price.

\section{FIGURE 2}

EFFICIENCY OF PRIVATE AND JUDICIAL AUCTIONS

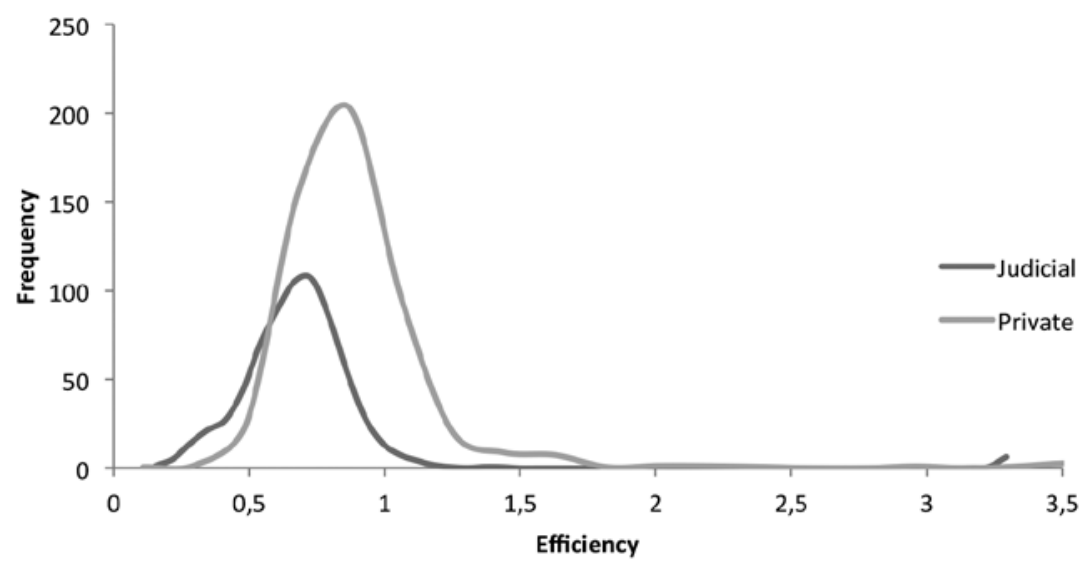

To test the magnitude and significance of the difference, we run two regressions to test whether the gross and net auction prices were affected by the nature of the auction. The specification of the model was: 
Where $J_{i 1}$ are dummies for the different Courts (private auctions, the base), and the sub index $i$ denotes car. Thus, the coefficient of each dummy show the percentage difference of the auction prices carried out by each court and the private auctions.

We use an integrated sample of 440 judicial and 1,038 private auctions. Table 2 shows the coefficients of the double log regressions that also control for the log of the market price, so that the coefficient of the dummies for Courts is the percentage difference between the private auctioneer (used as a base) and each Court. The results show that all dummy Court coefficients are negative and significant. More specifically, they show that judicial auctions, given a market price, are associated with a reduction in the price between $17.6 \%$ and $33 \%$, compared with the price in private auctions; this difference is not only statistically significant, but economically relevant, since it cannot be associated with an eventual difference in the market prices between the two types of auctions.

Whilst we are aware of the concern arising for the fact that not controlled differences in quality could explain part of the difference, the depuration of the data, the fact that the most plausible explanation for car's price variation is due to a lemon's effect, something presumably more severe in the case of voluntary auctions. Still, one could argue that in the case of the more adversarial judicial litigations, the cars are of worse quality, given the make and model year. While this reason is possible, it is unlikely to explain such a big difference. Instead, the magnitude of this difference suggests that there is a basis for the main concern regarding the efficiency of Judicial Auctions' regulation. In fact, our interpretation is consistent with a number of complaints that have characterized the judicial auctions institution: ${ }^{5}$

"There is a mafia" say those who participate in auctions.

"Roberto Martinez says this is a hobby. He buys trucks in judicial auctions in $\mathrm{Ch} \$ 2$ million and sells them three or four days after for Ch\$ 6 million. El Mercurio (2006).

Our interpretation is also consistent with the fact that when the plaintiff carries a big number of cases (Mitsui, in our sample), it affects the Court's decision on which auctioneer handles its cars, and in particular, skews toward a highly efficient auctioneers. Likewise, most banks avoid reaching the judicial level, and prefer direct negotiations with debtors.

5 The same type of complaints exist in other countries. See, for instance, a mention to "a blow to the auctioneer mafia" in Argentina. http://www.rankia.com/blog/ subastas-judiciales/488185-golpe-mafia-subastera 
TABLE 2

PRICE CUTS ASSOCIATED WITH JUDICIAL AUCTIONS

\begin{tabular}{|llllll|}
\hline & \multicolumn{2}{c}{ Ln (Auction Price) } & & \multicolumn{2}{c|}{ Ln (Net Auction Price) } \\
\cline { 2 - 3 } \cline { 5 - 6 } & Coef & Test t & & Coef & Test t \\
\hline J21 & -0.244 & -5.97 & & -0.234 & -5.08 \\
J23 & -0.316 & -6.8 & & -0.330 & -6.27 \\
J24 & -0.276 & -5.95 & & -0.277 & -5.31 \\
J25 & -0.203 & -4.27 & & -0.202 & -3.77 \\
J27 & -0.176 & -4.12 & & -0.178 & -3.67 \\
J29 & -0.250 & -6.33 & & -0.255 & -5.74 \\
J30 & -0.258 & -6.2 & & -0.255 & -5.45 \\
\hline Log Market Price & 0.773 & 48.15 & & 0.760 & 42.03 \\
\hline Const & 3.226 & 13.59 & & 3.280 & 12.29 \\
\hline R Square & 0.614 & & 0.548 & \\
\hline Adjusted R Square & 0.612 & & 0.546 & \\
\hline
\end{tabular}

\section{Conclusions}

The Chilean regulation reform on judicial auctions that took place in the early 1980s strove to reduce monopoly rents associated with practical monopolies and control corruption. The reform allowed anyone to be an auctioneer, limiting the capacity of judges to assign judicial auctions to particular auctioneers, something characteristic of many regulations. It also maintained maximum fees for judicial auctions, but liberalized fees in the case of voluntary auctions. We analyzed the effect of these two regulations aimed to protect consumers.

Applying a unique institutional framework, where both systems using English auctions coexist, we found systematic evidence that questions the protection of which the regulator tried to provide creditors when they resorted to judicial auctions. Auctioneers did not abide by the regulation, and they charged way higher fees than those stipulated by the ceiling; moreover, Courts did not appoint the auctioneers in a prescribed order. However, not complying with the law did not necessarily harm auction efficiency and could even have positive effects on it. Consistent with a simple model, we found evidence showing that the auctioneers performing worse from the debtors and creditors' viewpoint, a restricted but useful concept of social efficiency, were overrepresented. That is, judges appoint particularly those auctioneers that don't deliver good results. As derived from a simple incentive model, this is the predicted behavior of judges since the poor auction performance would be consistent with a private settlement, and eventually corruption.

Likewise, charging a higher price than that allowed is not necessarily perverse from an economic point of view if higher prices induce larger effort and thus, a better net price finally obtained by customers. However, our results suggest judicial auctions end up providing a value for debtors and debtors, those the law is intended to protect, which is estimated at $65 \%$ of the total provided by 
private auctions. On one hand, there is a natural concern about whether this huge reduction in prices may be explained by unobserved differences in quality, we argue that we controlled a significant part of the observed differences real buyers may observe. That is, our sample considers only cars in good condition based on detailed information. On the other hand, the adverse selection effect works in an opposite direction, suggesting that worse unobserved quality should prevail in voluntary auctions. While we accept the possibility that some bias may exist, literature shows that differences associated with unobserved quality are much smaller than those reflected in the price gap witnessed between voluntary and judicial auctions. Furthermore, the evidence that judges appoint auctioneers in non-random way, does not compare judicial and private auctions, so it is not sensitive to such a potential bias.

Some policy implications derived from the data and its consistency with our simple model of incentives are direct. Mandating Courts to rotate auctioneers with no consideration of their efficiency reduces the incentive auctioneers have to perform well. In turn, because private auctioneers build their reputation and clientele through achieved results, a natural incentive to perform well increases the present net margin. The policy implication is thus natural: judicial performance should be measured, at least in the cases where market prices are available.

To align judicial auctioneers' incentives with social welfare, it is necessary to associate judicial auctions and performance measurements, such as the ones suggested here. Courts should appoint the auctioneers with the best auction efficiency or bid the right to be the auctioneer on the basis of a promise of measured efficiency. By doing so, imposing a limit to fees-something that in practice hasn't had an effect-has no purpose.

In conclusion, the case of judicial auctions in Chile also illustrates how good intentions aimed at protecting consumers, may eventually end up harming them. Designing public policy also requires the consideration of economic incentives for public servants as a constraint to the general problem.

\section{REFERENCES}

Acemoglu, D. and J. Robinson (2012). Why Nations Fail: The Origins of Power, Prosperity and Poverty, Crown Business.

Abarca, P. (2006). "El monopolio legal del Conservador de Bienes Raíces", Dissertation, School of Engineering, Pontificia Universidad Católica de Chile.

Doyle, R. and S. Baska (2002). "From ancient Rome to tadays high-tech auctions", The National Auctioneers Museum, http://web.archive.org/ web/20080517071614/http://auctioneersfoundation.org/news_detail. php?id=5094

El Mercurio (2006). "Reportaje del Lunes", May 15th.

Harberger, A. C. (1985). "Observations on the Chilean Economy, 1973-1983". Economic Development and Cultural Change, 33v(3), pp. 451-62.

Honduras (2003). "Attaining the goals of the poverty reduction strategy", Progress Report, 2004-2006, Government of Honduras. http://www. sefin.gob.hn/pdfs. 
International Transparency (2006). “Transparency Indexes”, Internet Document, webpage: http://www.transparency.org/policy_research/surveys_indices

Kaufmann, D. (2005). "Myths and realities of governance and corruption", The World Bank, Chapter 21.

Klemperer, Paul (1999). "Auction Theory: A Guide to the Literature", Journal of Economic Surveys, Nuffield College, Oxford University.

Klemperer, Paul (2002). "How (Not) to Run Auctions: the European 3G Telecom Auctions", European Economic Review.

Levy, B. and P. Spiller (1977). Regulations, institutions and commitment: comparative studies in telecommunications, Cambridge: Cambridge University Press.

Llach, Ana María (1988). "Del carácter público de la función de los martilleros y su fiscalización”. Tesis (Licenciado en Ciencias Jurídicas y Sociales) - Universidad Católica de Valparaíso.

Paredes, R. and J. M. Sánchez (2004). "Government Concession Contracts in Chile: The Role of Competition in the Bidding Process", Economic Development and Cultural Change, 53, $\mathrm{N}^{\circ} 1: 215-34$.

Paredes, R. (1992). "Economic Regulation in Chile: The non Structural Option" (Spanish), in Economic Transformation in Chile, F. Larrain and R. Vergara eds. Centro de Estudios Públicos, Santiago, Chile.

Ramamurti, R. (ed.) (1996). Privitizing Monopolies in Developing Countries: Lessons form the Telecom and Transport Sectors in Latin America. John Hopkins University Press.

Rules of the Tennessee Auctioneer Commission (2004). "Rules of the TAC, Chapter 0160-1 regulations of auctioneers.

Shirley, Mary M. (2008). Institutions and Development. Cheltenham, UK and Northamptoin, MA: Edward Elgar, 2008). Cheltenham, UK and Northampton MA. Edward Elgar http://www.e-elgar.com/bookentry_mainUS.lasso?id=12524

Shubik, M. (1983): "Auctions, Bidding and Markets: A Historical Sketch", in R Engelbrecht-Wiggans et al., pp. 33-52.

Spiller, P. and L. Viana (1993). "How should it be done? Electricity regulation in Argentina, Brazil, Uruguay and Chile," in International comparison of electricity regulation, R. Gilbertand E. Khan, eds., Cambridge University Press.

Stone, A., B. Levy and R. Paredes (1996). "Public institutions and private transactions: a comparative analysis of the legal and regulatory environment for business transactions in Brazil and Chile", in Empirical Studies in Institutional Change, Alston, Eggertsson and North, eds., Cambridge University Press.

Stigler, G. (1971). "The Theory of Economic Regulation". Bell Journal of Economics and Management Science, № 3, pp. 3-18.

Valdés, D. (2006). "Libre Competencia y Monopolio", Editorial Jurídica de Chile Vickrey, W. (1961). "Counter speculation, Auctions and Competitive Sealed Tenders", Journal of Finance, 16, 8-37.

World Bank (2003). "Peru: Microeconomic Constraints to Growth, the Evidence from the Manufacturing Sector", Poverty Reduction and Economic Management Department and Financial, Private Sector and Infrastructure Department Country Management Unit September 30, 2003. 